\title{
Centro de Convivência Cultural de Campinas: Contexto e Inserção Urbana
}

\author{
Ana M. R. G. Monteiro (PQ), Larissa H. Werneck (IC).
}

\section{Resumo}

O Centro de Convivência Cultural de Campinas, projetado em 1967 pelo arquiteto Fábio Penteado, é uma das obras de arquitetura moderna mais significantes para a cidade. Localizado na atual Praça Imprensa Fluminense, foi projetado para servir a todas as camadas da população, proporcionando um local livre para manifestações culturais, artísticas e área de lazer. Esta pesquisa tem como objetivo principal entender o contexto onde o CCC foi inserido, estudar as transformações sofridas pela Praça I. F., desde a sua criação até a implantação do teatro, além de estudar a maneira como ele foi projetado e a sua relação com o meio.

Palavras Chave: Fábio Penteado, Centro de Convivência Cultural, Praça Imprensa Fluminense.

\section{Introdução}

Localizado na atual Praça Imprensa Fluminense, - Centro de Convivência de Campinas foi projetado em 1967, por Fábio Penteado. Seguindo a linha do arquiteto, o teatro foi projetado com cunho social, tendo como objetivo direto fazer a população se apropriar do espaço e proporcionar a todas as parcelas da sociedade a oportunidade de ter contato com eventos culturais e de lazer em geral. Esse trabalho tem como objetivo entender o contexto onde o CCC foi implantado e estudar as transformações da Praça Imprensa Fluminense até a criação do mesmo, visto que este sempre foi um local de encontro da população campineira. Os objetivos específicos da pesquisa incluem levantamento bibliográfico e iconográfico, e pesquisa em jornais da região.

\section{Resultados e Discussão}

Em 1965, o prefeito de Campinas, Ruy Novaes, manda demolir o Teatro Municipal da cidade. Insatisfeita, a população exige a construção de um novo teatro. Neste contexto surge o CCC, para suprir a necessidade de um teatro e, ao mesmo tempo, mantém o espaço de praça onde foi inserido, Praça Imprensa Fluminense.

A Praça I. F. surge onde existia o Passeio Público de Campinas. Ao final do século XIX, para suprir a falta de espaços públicos de lazer, surge 0 Passeio Público. Anos depois, se torna a atual praça. O local sofreu diversas transformações, inclusive foi um parque infantil, sempre foi um importante espaço de lazer para a população. $O$ CCC é composto por um teatro de ópera, um bar, uma área administrativa e uma galeria. Além disso, as coberturas destes quatro blocos voltamse para o centro da praça, onde formam um teatro de arena para oito mil pessoas, permitindo a apropriação de todos, a todo o momento.

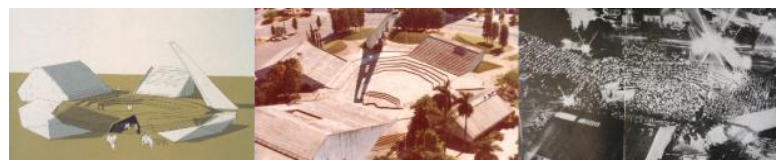

Figura 1: Centro de Convivência: projeto, edifício e utilização.

Conclusões

O Centro de Convivência supre uma necessidade que a cidade de Campinas tinha na época - a de um teatro - além de manter a característica de praça do local, que há muito tempo é um importante espaço de convívio para a população. Fábio Penteado conseguiu em seu projeto unir duas necessidades da cidade de Campinas, além disso, o CCC é ainda uma das obras de arquitetura moderna mais significativa da cidade e merece ser estudada, não só pela arquitetura, mas também pela sua proposta de inserção urbana.

\section{Agradecimentos}

Agradeço especialmente a Prof. ${ }^{\text {a }}$ Ana Goes, minha orientadora, pela dedicação e paciência ao longo deste semestre. E também o CNPq pelo incentivo através da bolsa de pesquisa.

LIMA, Siomara B. S. As Áreas Verdes no Plano de Melhoramentos de Campinas. Campinas: Revista Oculum Ensaios, 2002.

MONTEIRO, Ana M. G. Ramos de Azevedo e seu Projeto de Posturas para uma Nova Campinas. Campinas: Revista Oculum Ensaios, 2002.

PENTEADO, Fábio. Fábio Penteado: Ensaios de Arquitetura. São Paulo: Empresa das Artes, 1998.

TREVISAN, Ricardo. Centro de Convivência de Campinas: um olhar sobre a arquitetura de Fábio Penteado. São Paulo: Revista Risco, 2010. 